\title{
Firm's supply chain agility enabling resilience and performance in turmoil times
}

\section{Marcelo Bronzo Ladeira, Marcos Paulo Valadares de Oliveira, Paulo Renato de Sousa and Marcelo Werneck Barbosa*}

Facultad de Administración y Negocios,

Universidad Autónoma de Chile,

Pedro de Valdivia, 425 - Providencia - Santiago, Chile

Email: marcelobronzo@face.ufmg.br

Email: marcos.p.oliveira@ufes.br

Email: paulorenato@fdc.org.br

Email: marcelo.werneck@uautonoma.cl

${ }^{*}$ Corresponding author

\begin{abstract}
Facing a scenario of greater risk and turbulence, in which vulnerability and disruption events can impact firms' operations and supply chains, agility remains a key capability for its effects on performance and, especially important in turbulent periods, on firm's resilience. This paper presents the findings of a quantitative study that attempted to describe these effects. By means of a survey with a group of 305 top executives and management professionals in manufacturers of non-durable consumer goods operating in Brazil, this study describes agility taking into account the respondents' perception of the firm's internal limits as well as the upstream and downstream firms value chain processes. Structural equation modelling was used to analyse data and validate the research model. In terms of managerial contributions, the research findings suggest that investments must be directed at improving firms' integration and flexibility, especially if agility is considered a relevant competitive capability in operations strategy.
\end{abstract}

Keywords: supply chain agility; process integration; process flexibility; organisational resilience; competitive performance.

Reference to this paper should be made as follows: Ladeira, M.B., de Oliveira, M.P.V., de Sousa, P.R. and Barbosa, M.W. (2021) 'Firm's supply chain agility enabling resilience and performance in turmoil times', Int. J. Agile Systems and Management, Vol. 14, No. 2, pp.224-253.

Biographical notes: Marcelo Bronzo Ladeira is an Endowed Professor at the Department of Management of Federal University of Minas Gerais - Brazil. $\mathrm{He}$ holds a $\mathrm{PhD}$ in Operations Management from Universidade Federal de Minas Gerais. He was a visiting scholar at Università degli Studi di Bologna. $\mathrm{He}$ has published in different international scientific journals, such as Management Decision, Business Process Management Journal, Supply Chain Management: an International Journal, Harvard Business Review, Scientometrics and International Journal of Logistics Research and Applications, amongst others. His research focuses on different topics of 
business process management and organisational performance fields, such as maturity models, organisational resilience, firm's supply chain agility and business analytics.

Marcos Paulo Valadares de Oliveira is an Associate Professor at the Department of Management of Universidade Federal do Espírito Santo - Brazil and head of the TecPro (Technologies and Processes) research center. He holds a PhD in Operations Management from Universidade Federal de Minas Gerais. He was a visiting scholar at North Carolina State University (USA), Northwood University (USA), University of Shangai Jiao Tong (China) and University of Peking (China). He has received 368 citations regarding Web of Science (Factor H:7), 469 regarding SCOPUS (h-index 7) and 1253 regarding Google Scholar (h-index 12 and i10-index 15). His research interests comprise business analytics, business process management, supply chain management, maturity models and operational strategy.

Paulo Renato de Sousa holds a $\mathrm{PhD}$ in Knowledge transfer in Business Administration, a Master and a Bachelor degree in Business Administration from Pontifícia Universidade Católica de Minas Gerais. He is currently a Professor and Researcher at Fundação Dom Cabral (FDC) in the research field of purchasing, supplier development and logistics. He has authored several papers on logistics, operations, purchasing, supply chain management, value chain, and distribution channels.

Marcelo Werneck Barbosa is a Member of the Business and Management Department at Universidad Autónoma de Chile, Chile. He received his BSc and MSc in Computer Science and his PhD Business Administration (Operations Management and Logistics) from Universidade Federal de Minas Gerais, Brazil. His main research interests include business analytics and big data for supply chain management and sustainability. He has published papers in several journals and conferences, such as Journal of Cleaner Production, International Journal of Logistics Research and Applications, Scientometrics, Journal of the Association for Information Science and Technology and International Journal of Logistics Management and Systems.

\section{Introduction}

The COVID-19 pandemic has affected global supply chains of companies like Unilever at entry level from production to distribution. Regarding Marc Engel, Unilever's Chief Supply Chain Officer, emphasis on agility is helping Unilever's supply chain to go through coronavirus lockdowns and will allow the company to keep its sustainability initiatives on track. As stated by Engel, "At the end of the day, every dollar we spend on agility has probably got a $10 \mathrm{x}$ return on every dollar spent on forecasting or scenario planning" (Cosgrove, 2020).

Agility is a key competitive capability in addressing changes in contemporary business environments, which demand responsiveness, mass customisation, and product and process innovation (Ashrafi et al., 2019; Braunscheidel and Suresh, 2009; Dubey et al., 2014; Gligor et al., 2015; Gunasekaran and Yusuf, 2002; Swafford et al., 2008, 2006b; Yusuf et al., 2014). Especially for agile firms, turbulences like those brought by COVID-19 should not be seen just as threats but also as opportunities, since agility capabilities can favour competitive advantages (Ponomarov, 2012; Ponomarov and 
Holcomb, 2009; Vázquez-Bustelo and Avella, 2006). Sharifi and Zhang (1999) highlighted agility as an important characteristic for firms to be able to face change or disruptive situations, planned or not, successfully and quickly. In a report published by KPMG focused on a survey of 1300 CEOs of major corporations in 11 of the world's largest economies, agility was considered as a survival condition that guides the actions of CEOs of companies such as Northrop Gorman, Walmart, Siemens Gamesa, and Bridgestone.

The agility phenomenon may be described at different analytic levels (supply chains, firms, functions, processes, and process areas), and in many studies the term agility is related with a certain capability that a firm may pursue to face unforeseen changes in the marketplace and to respond to the need of customers always with high responsiveness and speed (Ashrafi et al., 2019). In the context of the firm's supply chain, agility is seen as a capability that is not limited by the inner efficiency of the firm, but also on the effectiveness of the firm in coordinating value flows with its suppliers and strategic customers.

Braunscheidel and Suresh (2009), described firm's supply chain agility (FSCA) as " $(\ldots)$ the capability of the firm, internally, and in conjunction with its key suppliers and customers, to adapt or respond in a speedy manner to marketplace changes as well as to potential and actual disruptions, contributing to agility of the extended supply chain". This broader connotation of agility in the context of the firm's value chain is consistent with the finding that agile firms are more oriented to markets (suppliers and customers) and are in better shape to quickly respond to market dynamics so as to ensure flows of supply and demand are matched. In this sense, the concept of agility necessarily involves the focal firm's downstream and upstream value chain flows in the processes areas of make, source and delivery (APICS, 2017).

The present study is based on and extends previous studies in the sense that it considers process integration and process flexibility as important antecedents of agility (Braunscheidel and Suresh, 2009; Swafford et al., 2006a, 2006b, 2008). It is clear that a process orientation perspective can be very useful for the objective of studying firm's agility, particularly in the context of supply chain processes areas. The study carried out by Swafford et al. (2006b), for instance, tested flexibility as an antecedent of agility in the areas of supply, fabrication, and delivery processes. Braunscheidel and Suresh (2009) investigated firm's supply chain antecedents, and specified market-oriented and learningoriented constructs as exogenous variables. These exogenous constructs, in turn, were related to processes integration levels, both internal and external processes (with key suppliers and direct customers), expanding the understanding of the importance of upstream and downstream links to explain the firms' agility results.

In addition to antecedents, there is an increasing number of studies seeking to investigate the effects of agility on endogenous variables, such as organisational resilience. When faced with a disruption, firms that are more agile are more likely to mitigate the effects of these events, reducing potential deleterious outcomes on the integrity of the physical, financial, information, and service flows between the firm and other chain members (Craighead et al., 2007; Scholten and Schilder, 2015). There is growing recognition that agility also brings competitive advantages to the firm (KPMG, 2019), especially in difficult competitive scenarios marked by intense competition, uncertainty, volatility, and new types of vulnerability. By being more agile, firms can be more resilient, becoming more prosperous and competitive, either because they are able to anticipate disruptive events or because they are faster and more effective in mitigating 
the effects of those events (Akter et al., 2016; Dubey et al., 2018; Gligor et al., 2015; Ponomarov, 2012).

In this study we describe the effects of process integration and flexibility on firm's supply chain agility, competitive performance and organisational resilience. In order to investigate the effects of integration over agility, we rely on the Relational View of the firm (Dyer and Singh, 1998) as the theoretical basis to explain the relationship considering integration as a relational competence (Wieland and Wallenburg, 2013). For the effects of flexibility over agility and agility over performance, we rely on Dynamic Capabilities theory (Teece, 2007) by considering that flexibility can be taken as a dynamic capability since it is dedicated to the modification of operating routines, facilitates resource reconfiguration and enables sensing and capitalising opportunities and threats (Teece, 2007; Zollo and Winter, 2002). In this sense, we use both the Relational View of the firm and the Dynamic Capabilities theory to explain the possible effects of the agility, reconfiguring supply chain resources and working collaboratively with supply chain partners, over both resilience and competitive performance.

The research universe comprised Brazilian manufacturers of non-durable consumer goods, a sector in which firms operate in intermediate and final markets with very high performance and competitiveness requirements. Data were collected using an electronic survey with 305 key informants occupying strategic management positions, and were analysed, and the model tested, using structural equation modelling.

For the studies in the field of operations management, this research contributes by validating hypotheses that test the direct and simultaneous effects of process integration and process flexibility on agility, and, indirectly, on organisational resilience. Besides, this study carries out such investigation using a value chain perspective, emphasising a process orientation (a horizontal focus) and deemphasising organisational or functional orientation (vertical focus). It seeks a more comprehensive view of agility in this sense, in a value stream perspective of the source, make and delivery process areas. To practitioners, this study shows that organisations should invest on agility in order to be more resilient and to improve their organisational performance. Moreover, we expect this study to stimulate organisations to adopt an agile culture.

The remainder of this paper is organised as follows. Section 2 presents the theoretical foundations that support the present study, and delineates the research hypotheses. Section 3 focuses on methodological details. Section 4 presents the results of the study. Section 5 discusses the findings, identifying contributions to the literature and management practice as well as limitations of the study. Finally, implications and future research suggestions are offered in Section 6.

\section{Theoretical background and hypotheses}

Agility is based not only on responsiveness and flexibility but also on cost and quality of goods and services (Matawale et al., 2015). Agile supply chains focus on responding quickly to changing market demands and needs (Haq and Boddu, 2015). An agile supply chain needs to cope with uncertainty. In this era of business competition and turbulences that demands real time decisions, agile supply chains must be able to quickly meet customers' requirements even in peak conditions or lack of demand (Mustafid et al., 2018). 
The scope of firm's supply chain agility includes the context of the firm's internal processes as well as its external processes with first-tier (direct) suppliers and customers. Specifically, it has been found that FSCA antecedents are related to the levels of integration of the firm's internal and external processes with suppliers and direct customers (Braunscheidel and Suresh, 2009).

Process integration is not only associated with higher levels of agility of the firm, but also supports firms in managing risks and disrupting events in their supply chains. This suggests an important relationship between process integration and resilience. Evidence of such associations is presented in studies like Wieland and Wallenburg (2013) that describe how process integration favours visibility, rapid detection of vulnerabilities, and implementation of effective response by firms to risky situations or disruptive events in their supply chains. The first hypothesis of this study was elaborated with that in mind:

H1: Process integration and firm's supply chain agility are positively correlated.

Considering process integration as vital for any supply chain management effort, and that internal and external integration are distinct but closely related concepts (Chen et al., 2009), it is beneficial to examine both when studying supply chain integration (Rodrigues et al., 2004). Therefore, we have two sub-hypotheses, concerning the effects of integration over agility:

\section{H1a: Internal process integration positively affects the firm's supply chain agility}

H1b: External process integration (with first-tier suppliers and customers) positively affects the firm's supply chain agility.

Another important antecedent of agility is organisational flexibility. According to Zhang (2011), flexibility is a capability that allows companies to modify the way they execute their tasks, activities, or processes and thus achieve different goals from the same original set of resources. In previous studies, such as by Upton (1994) and Slack (1983), flexibility has been described as resulting from the range of states that can be assumed by a system, taking into account the cost required to move the system from one state to another, as well as the time required for this adjustment to occur. In these and other studies, such as those of Zhang et al. (2002), Grewal and Tansuhaj (2001) and Gupta and Somers (1992), flexibility is defined as the ability of a firm to react to situations or events with reduced penalty of time or cost, and move to new states more favourable for organisational performance.

Flexibility and agility are distinct but interrelated concepts (Swafford et al., 2008), with flexibility perhaps being the main or most important feature of an agile organisation (Christopher and Towill, 2001). Flexibility thus comprises the ability of the firm to go from the current state to a known and planned state, given that the system is prepared for future transformations, but within certain, previously defined limits (Bernardes and Hanna, 2009). Swafford et al. (2008), for example, identify a firm's supply chain flexibility as an important condition for reducing lead times, ensuring good use of a firm's installed capacity, and the efficient adjustment of mix and production volumes.

Thus, based on the foregoing, we tested a second hypothesis, in this study:

H2: Flexibility and firm's supply chain agility are positively correlated.

However, flexibility is a domain that involves different dimensions, since it is possible to find different forms of flexibility, in different types of processes, and also in different 
intensities, as identified in many earlier studies (Slack, 1987, 1991; Swafford et al., 2006a; Upton, 1995). The seminal investigation of Sethi and Sethi (1990), for instance, listed at least fifty types of flexibility in processes and operations, as well as suggested measures, indicators and results from empirical studies. More recently, different studies departure from the premise that flexibility has to be investigated in a more comprehensive and systemic perspective, in the context of the supply chain management processes (Gligor, 2018; Stevenson and Spring, 2007). Therefore, within the purpose of our work, we developed three sub-hypotheses, regarding the effects of flexibility over supply chain agility:

H2a: Source Process Flexibility positively affects the level of the firm's supply chain agility.

H2b: Make Process Flexibility positively affects the level of the firm's supply chain agility.

H2c: Deliver Process Flexibility positively affects the level of the firm's supply chain agility.

Agility can affect the performance of firms and supply chains in a range of relevant performance dimensions (Gligor et al., 2015), and has been linked to results in different performance areas: service level fulfilment, orders completed on time, and delivery reliability. It is also linked to coping with disruptions in supply processes as well as to financial outcomes, particularly return on investment (Christopher and Peck, 2004; Gligor et al., 2015; Pettit et al., 2013).

Despite years of research, further studies are needed to better explain how, under what conditions, and at what level, agility affects firm performance. The difficulty arises, first, because agility is a multidimensional construct, comprising different dimensions, such as the levels of integration and flexibility of business processes, constructs that are also difficult to measure directly, given the high level of abstraction. Another difficulty is related to firm performance, which can depend on many different actions or practices, not necessarily related to the agile approach but guided by, for example, lean production precepts and the Six Sigma methodology. From these arguments, we formulate the third hypothesis of this study:

H3: Firm's supply chain agility positively affects firm's overall performance, on costs and service level.

Jüttner and Maklan (2011) defined organisational resilience as a firm's adaptive capability linked to its effectiveness to resist disruptions, and to mitigate quickly, if necessary, the deleterious impacts of such disruptions. Ponomarov and Holcomb (2009) conceptualised resilience in supply chain processes as " (...) the adaptive capability of the supply chain to prepare for unexpected events, respond to disruptions, and recover from them by maintaining continuity operations at the desired level of connectedness and control over structure and function". According to this definition, resilience results from proactive actions in the dynamic configuration and/or reconfiguration of competencies at the operational level, an important condition to deal with new forms of vulnerabilities and risks. Colicchia and Strozzi (2012) also conceptualised resilience as a proactive approach to risk management, highlighting, however, a problem of practical interest related to the firm's degree of orientation to identify risks and vulnerabilities in their supply chains. 
Agility is of utmost importance in increasing supply chain resilience, as more agile companies respond better and faster to the ever-changing demands on their markets (Christopher, 2000; Christopher and Peck, 2004; Pereira et al., 2014). Thus, this leads to the fourth and final hypothesis of the present study:

H4: Firm's supply chain agility positively affects organisational resilience.

\section{Research method}

The constructs presented in the research hypotheses form the research model and were defined based on previously published studies, identified in our literature review. Table 1 presents the first-order constructs of the model, their definition and the references from which they were defined.

Table 1 First order constructs

\begin{tabular}{|c|c|c|}
\hline Construct & Definition & References \\
\hline \multirow[t]{4}{*}{$\begin{array}{l}\text { Process } \\
\text { integration }\end{array}$} & \multirow{4}{*}{$\begin{array}{l}\text { Resource coordination between the organisation's key } \\
\text { processes, comprising the firm's internal and external } \\
\text { processes, with first-tier suppliers and customers, } \\
\text { through which a wide range of activities are carried out } \\
\text { collectively, by different areas of the business and } \\
\text { stakeholders, with the purpose of creating value and } \\
\text { meeting the organisation's performance objectives and } \\
\text { strategic goals. }\end{array}$} & $\begin{array}{l}\text { Bronzo et al. } \\
\text { (2013) }\end{array}$ \\
\hline & & $\begin{array}{l}\text { Braunscheidel and } \\
\text { Suresh (2009) }\end{array}$ \\
\hline & & $\begin{array}{l}\text { Lockamy and } \\
\text { McCormack } \\
(2004)\end{array}$ \\
\hline & & $\begin{array}{l}\text { Trkman et al. } \\
(2007)\end{array}$ \\
\hline $\begin{array}{l}\text { Process } \\
\text { flexibility }\end{array}$ & $\begin{array}{l}\text { The firm's ability to modify or react to changing } \\
\text { requirements in its business processes, internal and } \\
\text { external, without major penalties for time, effort, cost } \\
\text { or performance }\end{array}$ & Upton (1994) \\
\hline \multirow{2}{*}{$\begin{array}{l}\text { Firm's supply } \\
\text { chain agility }\end{array}$} & \multirow{2}{*}{$\begin{array}{l}\text { A risk management initiative that enables the firm to } \\
\text { respond rapidly to market place changes, as well as to } \\
\text { potential and actual disruptions in the supply chain. } \\
\text { Therefore, agility is of value for both risk mitigation } \\
\text { and response to unforeseen shifts in marketplace } \\
\text { environment. }\end{array}$} & Gligor et al. (2015) \\
\hline & & $\begin{array}{l}\text { Swafford et al. } \\
\text { (2006a) }\end{array}$ \\
\hline \multirow{2}{*}{$\begin{array}{l}\text { Firm's } \\
\text { resilience }\end{array}$} & \multirow{2}{*}{$\begin{array}{l}\text { The adaptive capability of the supply chain to prepare } \\
\text { for unexpected events, respond to disruptions, and } \\
\text { recover from them by maintaining continuity } \\
\text { operations at the desired level of connected ness and } \\
\text { control over structure and function. }\end{array}$} & Ponomarov (2012) \\
\hline & & Pettit et al. (2013) \\
\hline \multirow[t]{3}{*}{$\begin{array}{l}\text { Firm's overall } \\
\text { performance }\end{array}$} & \multirow{3}{*}{$\begin{array}{l}\text { Competitive performance of the firm, considering the } \\
\text { dimensions of cost, profitability, market share and } \\
\text { service levels }\end{array}$} & $\begin{array}{l}\text { Bronzo et al. } \\
\text { (2013) }\end{array}$ \\
\hline & & Blome et al. (2013) \\
\hline & & $\begin{array}{l}\text { Trkman et al. } \\
(2010)\end{array}$ \\
\hline
\end{tabular}

Table 2 presents the questionnaire items for all constructs of the model and the main studies from which these items were extracted. 
Table 2 Survey items

\begin{tabular}{|c|c|c|c|}
\hline Constructs & Item id & Item description & References \\
\hline \multirow{7}{*}{$\begin{array}{l}\text { Process } \\
\text { integration } \\
\text { with key } \\
\text { suppliers } \\
\text { PIS }\end{array}$} & \multirow[t]{2}{*}{ PIS1 } & \multirow{2}{*}{$\begin{array}{l}\text { There is intense information sharing } \\
\text { between your company and your strategic } \\
\text { suppliers }\end{array}$} & $\begin{array}{l}\text { Braunscheidel and } \\
\text { Suresh (2009) }\end{array}$ \\
\hline & & & Frohlich and \\
\hline & \multirow[t]{2}{*}{ PIS2 } & \multirow{2}{*}{$\begin{array}{l}\text { Your company has a policy of giving } \\
\text { constant feedback to its strategic suppliers, } \\
\text { especially on issues related to product } \\
\text { quality and delivery performance }\end{array}$} & Westbrook (2002) \\
\hline & & & $\begin{array}{l}\text { Van Hoek et al. } \\
(2001)\end{array}$ \\
\hline & \multirow[t]{2}{*}{ PIS3 } & \multirow{2}{*}{$\begin{array}{l}\text { Meetings between your company's top } \\
\text { management and its strategic suppliers are } \\
\text { routine }\end{array}$} & $\begin{array}{l}\text { Kohlbacher } \\
(2010)\end{array}$ \\
\hline & & & \multirow{2}{*}{$\begin{array}{l}\text { McCormack et al. } \\
(2003)\end{array}$} \\
\hline & PIS4 & $\begin{array}{l}\text { The company is aware of opportunities to } \\
\text { improve process integration with its } \\
\text { strategic suppliers }\end{array}$ & \\
\hline \multirow{7}{*}{$\begin{array}{l}\text { Process } \\
\text { integration } \\
\text { with key } \\
\text { customers } \\
\text { PIC }\end{array}$} & \multirow[t]{2}{*}{ PIC1 } & \multirow{2}{*}{$\begin{array}{l}\text { There is intense information sharing } \\
\text { between your company and your strategic } \\
\text { customers }\end{array}$} & $\begin{array}{l}\text { Braunscheidel and } \\
\text { Suresh (2009) }\end{array}$ \\
\hline & & & Frohlich and \\
\hline & \multirow[t]{2}{*}{ PIC2 } & \multirow{2}{*}{$\begin{array}{l}\text { Your company has a policy of seeking } \\
\text { constant feedback from its strategic } \\
\text { customers, especially in terms of product } \\
\text { quality and delivery performance }\end{array}$} & Westbrook (2002) \\
\hline & & & $\begin{array}{l}\text { Van Hoek et al. } \\
(2001)\end{array}$ \\
\hline & \multirow[t]{2}{*}{ PIC3 } & \multirow{2}{*}{$\begin{array}{l}\text { Meetings between your company's top } \\
\text { management and its strategic clients are } \\
\text { routine }\end{array}$} & $\begin{array}{l}\text { Kohlbacher } \\
(2010)\end{array}$ \\
\hline & & & \multirow{2}{*}{$\begin{array}{l}\text { McCormack et al. } \\
(2003)\end{array}$} \\
\hline & $\mathrm{PIC} 4$ & $\begin{array}{l}\text { Your company is aware of opportunities to } \\
\text { improve process integration with its } \\
\text { strategic customers }\end{array}$ & \\
\hline \multirow{8}{*}{$\begin{array}{l}\text { Internal } \\
\text { process } \\
\text { integration } \\
\text { INTI }\end{array}$} & \multirow[t]{2}{*}{ INT1 } & \multirow{2}{*}{$\begin{array}{l}\text { The company's functional areas are } \\
\text { connected by corporate systems and with } \\
\text { centralised storage of data and information, } \\
\text { such as ERP, CRM, VMI, S\&OP, and others }\end{array}$} & $\begin{array}{l}\text { Braunscheidel and } \\
\text { Suresh (2009) }\end{array}$ \\
\hline & & & $\begin{array}{l}\text { Kohlbacher } \\
(2010)\end{array}$ \\
\hline & INT2 & $\begin{array}{l}\text { In the company, work teams of professionals } \\
\text { from various functional areas are common }\end{array}$ & $\begin{array}{l}\text { McCormack et al. } \\
\text { (2003) }\end{array}$ \\
\hline & INT3 & $\begin{array}{l}\text { Formal meetings and meetings with } \\
\text { employees from different functional areas } \\
\text { are routinely scheduled in the company }\end{array}$ & $\begin{array}{l}\text { Willaert et al. } \\
(2007)\end{array}$ \\
\hline & INT4 & $\begin{array}{l}\text { The company's senior management is } \\
\text { committed to the integration and } \\
\text { improvement of key operations processes } \\
\text { (such as purchasing, production, and } \\
\text { distribution) }\end{array}$ & \\
\hline & INT5 & $\begin{array}{l}\text { Does the company have any methodology for } \\
\text { mapping processes? }\end{array}$ & \\
\hline & INT6 & $\begin{array}{l}\text { The company has some methodology for } \\
\text { discovering opportunities for process } \\
\text { improvements }\end{array}$ & \\
\hline & INT7 & $\begin{array}{l}\text { The organisation's performance goals are } \\
\text { more business process oriented than the } \\
\text { organisational chart functions }\end{array}$ & \\
\hline
\end{tabular}


Table 2 Survey items (continued)

\begin{tabular}{|c|c|c|c|}
\hline Constructs & Item id & Item description & References \\
\hline $\begin{array}{l}\text { Source process } \\
\text { flexibility }\end{array}$ & SF1 & $\begin{array}{l}\text { Our company maintains a high frequency of } \\
\text { resupply with its strategic suppliers }\end{array}$ & $\begin{array}{l}\text { Braunscheidel and } \\
\text { Suresh (2009) }\end{array}$ \\
\hline \multirow[t]{4}{*}{$S F$} & SF2 & $\begin{array}{l}\text { Our company experiences no risk of product } \\
\text { outages from its strategic suppliers }\end{array}$ & \multirow[t]{4}{*}{$\begin{array}{l}\text { Swafford et al. } \\
\text { (2006b, 2006a, } \\
2008)\end{array}$} \\
\hline & SF3 & $\begin{array}{l}\text { If necessary, our company can change } \\
\text { delivery dates and/or times with its strategic } \\
\text { suppliers }\end{array}$ & \\
\hline & SF4 & $\begin{array}{l}\text { The company can change, if necessary, the } \\
\text { requested item quantities from its strategic } \\
\text { suppliers }\end{array}$ & \\
\hline & SF5 & $\begin{array}{l}\text { In the event of a breakdown (unavailability) } \\
\text { with any of your strategic suppliers, your } \\
\text { company may hire new suppliers for that } \\
\text { good and/or service }\end{array}$ & \\
\hline $\begin{array}{l}\text { Make process } \\
\text { flexibility }\end{array}$ & MF1 & $\begin{array}{l}\text { Our company can adjust its production } \\
\text { volumes if necessary }\end{array}$ & $\begin{array}{l}\text { Braunscheidel and } \\
\text { Suresh (2009) }\end{array}$ \\
\hline \multirow[t]{2}{*}{$M F$} & MF2 & $\begin{array}{l}\text { Our company can cut production times if } \\
\text { necessary }\end{array}$ & \multirow{2}{*}{$\begin{array}{l}\text { Swafford et al. } \\
\text { (2006b, 2006a, } \\
2008)\end{array}$} \\
\hline & MF3 & $\begin{array}{l}\text { Our company can produce multiple types or } \\
\text { families of products without major set up } \\
\text { costs }\end{array}$ & \\
\hline \multirow{6}{*}{$\begin{array}{l}\text { Deliver } \\
\text { process } \\
\text { flexibility } \\
\text { DF }\end{array}$} & DF1 & $\begin{array}{l}\text { Our company can change its delivery } \\
\text { schedule to meet new requests from its }\end{array}$ & $\begin{array}{l}\text { Braunscheidel and } \\
\text { Suresh (2009) }\end{array}$ \\
\hline & & strategic customers & \multirow{5}{*}{$\begin{array}{l}\text { Swafford et al. } \\
(2006 \mathrm{~b}, 2006 \mathrm{a} \\
2008)\end{array}$} \\
\hline & DF2 & $\begin{array}{l}\text { Our company can cope with variations in } \\
\text { demand for its products without relying on } \\
\text { high volumes of finished product inventories }\end{array}$ & \\
\hline & DF3 & $\begin{array}{l}\text { The number of distribution facilities and } \\
\text { agents in the distribution channels for our } \\
\text { products is sufficient }\end{array}$ & \\
\hline & DF4 & $\begin{array}{l}\text { Our company can adjust the quantities of } \\
\text { inventory in transit and allocated at its } \\
\text { distribution centers if necessary }\end{array}$ & \\
\hline & DF5 & $\begin{array}{l}\text { Our company has contracts with a sufficient } \\
\text { (adequate) number of carriers/logistics } \\
\text { service providers }\end{array}$ & \\
\hline $\begin{array}{l}\text { Firm's supply } \\
\text { chain agility }\end{array}$ & FSCA1 & $\begin{array}{l}\text { Our company can quickly adapt to changing } \\
\text { demands imposed by its consumers }\end{array}$ & $\begin{array}{l}\text { Blome et al. } \\
(2013)\end{array}$ \\
\hline \multirow[t]{5}{*}{$F S C A$} & FSCA2 & & $\begin{array}{l}\text { Gligor et al. } \\
(2015)\end{array}$ \\
\hline & & demands imposed by its competitors & \multirow{2}{*}{$\begin{array}{l}\text { Gunasekaran and } \\
\text { Yusuf (2002) }\end{array}$} \\
\hline & FSCA3 & Our company can launch new products with & \\
\hline & & high frequency & \multirow{2}{*}{$\begin{array}{l}\text { Swafford et al. } \\
(2008)\end{array}$} \\
\hline & FSCA4 & $\begin{array}{l}\text { Our company can continually improve the } \\
\text { quality of its products/services }\end{array}$ & \\
\hline
\end{tabular}


Table 2 Survey items (continued)

\begin{tabular}{|c|c|c|c|}
\hline Constructs & Item id & Item description & References \\
\hline \multirow{5}{*}{$\begin{array}{l}\text { Firm's supply } \\
\text { chain agility } \\
\text { FSCA }\end{array}$} & FSCA5 & $\begin{array}{l}\text { Our company is quick to adjust service levels } \\
\text { to meet the changing demands of its strategic }\end{array}$ & \multirow{5}{*}{$\begin{array}{l}\text { Teece et al. } \\
\text { (1997) } \\
\text { Zhang (2011) }\end{array}$} \\
\hline & FSCA6 & $\begin{array}{l}\text { Our company is able to quickly adjust its } \\
\text { capacity levels or production volumes if } \\
\text { necessary }\end{array}$ & \\
\hline & FSCA7 & $\begin{array}{l}\text { Our company is able to quickly reduce } \\
\text { production times if necessary }\end{array}$ & \\
\hline & FSCA8 & $\begin{array}{l}\text { Our company is proactive in the face of both } \\
\text { threats and opportunities arising from } \\
\text { relationships with your suppliers and strategic } \\
\text { customers }\end{array}$ & \\
\hline & FSCA9 & $\begin{array}{l}\text { Most of the workforce in the company can be } \\
\text { quickly trained to perform new tasks as } \\
\text { needed }\end{array}$ & \\
\hline \multirow{7}{*}{$\begin{array}{l}\text { Firm's } \\
\text { resilience } \\
\text { FRES }\end{array}$} & \multirow[t]{3}{*}{ FRES1 } & \multirow{2}{*}{$\begin{array}{l}\text { Taking as a reference a recent situation } \\
\text { experienced by your organisation, in which an } \\
\text { unexpected breakdown event occurred in your } \\
\text { company's supply chain, it can be said that at } \\
\text { that time: }\end{array}$} & $\begin{array}{l}\text { Ponomarov } \\
(2012)\end{array}$ \\
\hline & & & \multirow[t]{6}{*}{$\begin{array}{l}\text { Pettit et al. } \\
(2013)\end{array}$} \\
\hline & & $\begin{array}{l}\text { Your company was able to respond to the } \\
\text { disruption situation in order to quickly restore } \\
\text { normal production flows }\end{array}$ & \\
\hline & FRES2 & $\begin{array}{l}\text { Our company was well prepared to deal with } \\
\text { potential financial effects from the disruption }\end{array}$ & \\
\hline & FRES3 & $\begin{array}{l}\text { Our company was able to maintain a } \\
\text { satisfactory level of connectivity with other } \\
\text { supply chain agents during the impact period } \\
\text { of the disruption }\end{array}$ & \\
\hline & FRES4 & $\begin{array}{l}\text { Our company has been able to maintain a } \\
\text { satisfactory level of function }\end{array}$ & \\
\hline & FRES5 & $\begin{array}{l}\text { Our company was able to draw important } \\
\text { lessons and learn something relevant from } \\
\text { that situation }\end{array}$ & \\
\hline \multirow{6}{*}{$\begin{array}{l}\text { Firm's overall } \\
\text { performance } \\
\text { FOP }\end{array}$} & FOP1 & \multirow{2}{*}{$\begin{array}{l}\text { In terms of fulfilling customer base order } \\
\text { requests, the company has a level of service } \\
\text { considered to be similar or higher than its } \\
\text { strongest direct competitor }\end{array}$} & $\begin{array}{l}\text { Blome et al. } \\
(2013)\end{array}$ \\
\hline & & & \multirow[t]{5}{*}{$\begin{array}{l}\text { Trkman et al. } \\
(2010)\end{array}$} \\
\hline & FOP2 & $\begin{array}{l}\text { Our company's cost performance can be } \\
\text { considered equivalent to or better than your } \\
\text { strongest direct competitor }\end{array}$ & \\
\hline & FOP3 & $\begin{array}{l}\text { There has been an increase in the company's } \\
\text { profitability in the last } 5 \text { years }\end{array}$ & \\
\hline & FOP4 & $\begin{array}{l}\text { The company has been able to build customer } \\
\text { loyalty }\end{array}$ & \\
\hline & FOP5 & $\begin{array}{l}\text { The company has been able to attract new } \\
\text { customers to its business }\end{array}$ & \\
\hline
\end{tabular}


Figure 1 provides a visualisation of the theoretical-conceptual model. A detailed description of the relationships between the constructs in the structural model's path diagram is presented after Figure 1.

Figure 1 Structural research model

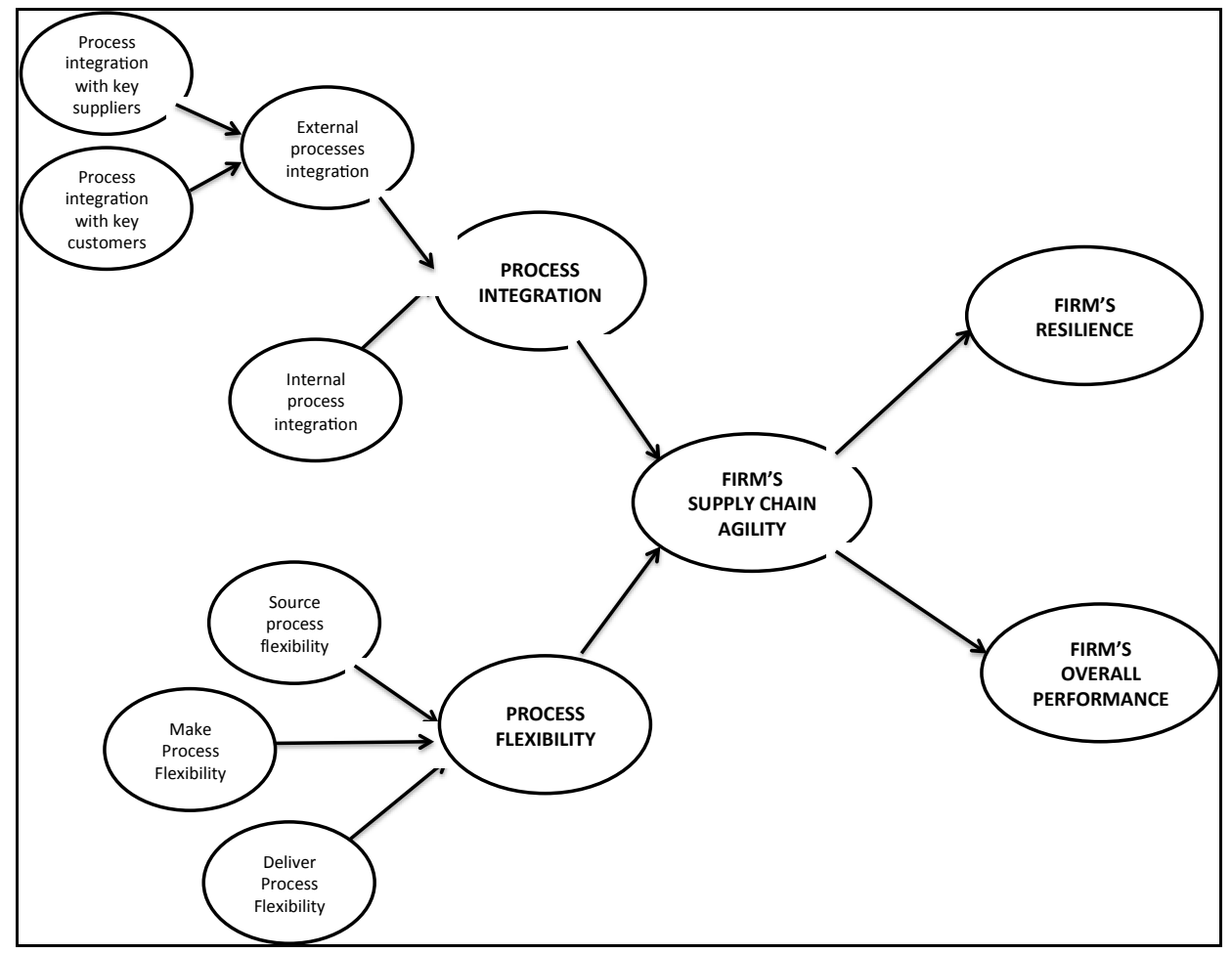

By the path diagram of the structural model, and considering the cause-and-effect relationships between the latent variables of the model, we claim that the exogenous variables process integration and process flexibility produce direct effects on firm's supply chain agility (FSCA).

The process integration construct is a latent variable consisting of two constructs: Internal Integration and External Integration (with strategic suppliers and customers). The level of internal integration was measured with different items: the use of corporate management and data processing systems; the commitment of top management to improve processes in areas of the firm's value chain (supply, production and distribution); the presence of formal methodologies for mapping business processes; the frequency of meetings between members of different functional areas; the presence of multifunctional teams to deal with problems and propose improvements in the firm's business processes and its supply chain. The level of external integration, in turn, was measured by taking into account measurement items aimed at describing relevant aspects of the firm's relationship with its first-tier strategic suppliers and clients. These constructs are comprised of measurement items that attempt to describe the frequency of contact between agents, the degree of sharing of strategic information, as well as the relationship orientation towards the improvement of products and processes, among other variables. 
To help survey respondents identify typical strategic company relationships, a brief definition of the concept was inserted at the beginning of the questionnaire: "consider as strategic those suppliers and customers with whom your company realises/move the largest financial volumes, or who are particularly important because they promote any other competitive advantages perceived as important by your company".

The Process Flexibility is a second order latent variable in the model, composed of three first order constructs, one for each process area of the firm's value chain: source, make and delivery. Items such as replenishment frequency, ease of changing dates, lead times, or quantities of items in purchase orders from vendors have been considered indicative of greater flexibility in source process. With regard to flexibility in make processes, in addition to economies of scope in operation, flexibility reflects the ability of companies to adjust their production volumes or the times involved in their manufacturing activities if necessary. Flexibility in deliver processes, on the other hand, is reflected in the ability of companies to dynamically change their delivery schedules, or to be able to cope with demand variability without high volumes of inventory (of finished goods) and to adjust inventory quantities in transit. Greater flexibility in deliver processes also requires companies to make investments in a sufficient number (appropriate to their needs) of distribution facilities, agents in distribution channels, as well as logistics service providers.

The path diagram in the structural model assumes that process integration and flexibility affect the firm's agility levels. In the research model, agility is evaluated as a capability that allows companies to adapt faster to changes imposed not only by their customers, but also by their competitors. Agility is also associated with the ability of the firm's employees to be trained to quickly and, if necessary, take on new tasks or perform new activities. Also, a sign of dynamism, agility is reflected in the short time to launch new products, or rapid incremental improvements in the quality of products and services marketed by the firm. Agility is also associated with the speed with which the firm is able to adjust its volumes and production lead times, seeking, for example, to reduce its costs of marketing mediation. Finally, greater agility is also associated with the capacity demonstrated by companies to be proactive in the face of threats and opportunities, when faced with unforeseen situations or those requiring changes.

In the structural model, the premise is that agility promotes positive effects both on competitive performance and on the level of resilience of firms. The latent variable Firm's Overall Performance is a multi-dimensional construct with several measurement items attempting to measure how effectively firms are in achieving key business objectives. For reasons of parsimony, such items do not measure performance results at disaggregated levels, describing, for example, the performance of functional areas. Competitive performance has been measured by key business performance indicators, such as the firm's effectiveness in building customer loyalty and attracting new customers to its business. Superior competitive performance is also associated with increased business cost efficiency, or business profitability growth, as well as higher levels of service when meeting customer order requirements.

Finally, we sought to describe the effects of agility on organisational resilience results. The path diagram, in the structural model, reflects an almost intuitive orientation: more agile companies are also more resilient, and resilience can be explained, at some level, by the degree of agility of the firm's supply chain. In this sense, given the peculiarity of the pathway method, the structural model has allowed us to contemplate both the direct effects of agility on resilience and also the indirect effects, of process 
integration and flexibility, on the firm's levels of resilience. In order to access data regarding the resilience measurement items, respondents were asked to recall any disruptive events that occurred in the company's supply chain in a recent period. In light of that experience, the firm's resilience in the event was measured from some parameters, such as the recovery time of the firm's normal production flows and how prepared the organisation was to deal with the financial effects of such a disruption. Organisational resilience was also measured by taking into account the firm's ability to maintain connectivity with other agents in its supply chain when a disruption event occurred, and if the firm was able to learn or draw important lessons from the event.

All measurement models are reflective in nature, allowing us to observe the effects of latent variables (constructs) on the respective measurement items. A structured method of prospecting and data analysis was adopted to investigate correlations and ordered pairs of relationships among variables and constructs of the hypothetical-conceptual model (Hair et al., 2017). A survey was used to access data from a sample extracted from the universe of Brazilian manufacturers of non-durable consumer goods.

The target population was composed of companies linked to Fundação Dom Cabral (FDC). According to the British Financial Times newspaper, FDC is among the top ten business schools in the world and is the best positioned among all organisations in this sector in Latin America. Survey respondents (key informants) are professionals with management expertise in the areas of operations and processes, including strategic sourcing, logistics and supply chain, marketing and sales. Specifically, for the purpose of describing the sample of respondents, the observation units consisted of four groups:

i CEOs, Directors, and Superintendents

ii functional area directors

iii functional area managers

iv functional area advisors/supervisors.

At the time of the present study, the FDC database consisted of 4820 companies, all active in production chains of non-durable consumer goods in Brazil. The sample was defined by the criterion of accessibility. Successive waves of invitation letters were sent to companies and continuous monitoring of the return rate of completed questionnaires was used to try to ensure an appropriate sample size, and also some diversification of company size and type of manufactured products. In more detail, for the purposes of data collection, emails were sent to key informants in each company, explaining the rationale of the study and describing the appropriate profile of survey respondents. We applied an online questionnaire, accessed and answered by respondents working in activities of strategic planning, management and control of processes and operations. Over 4 months (September - December/2019), 311 completed questionnaires were received, of which six were eliminated due to an excessive amount of missing data.

Partial least squares path modelling (PLS-PM) (Sanchez, 2013) was used to analyse the data in the $\mathrm{R}$ software package ( $\mathrm{R}$ Core Team, 2016). PLS-PM is considered appropriate for studies that are oriented primarily to scale validation and theory development, testing associations among blocks of variables. Such studies almost always involve models of paths that, when validated, explain the variation of dependent constructs and identify the relevance of exogenous effect-driving constructs in the structural model. PLS-PM is also recommended for situations where models are complex, 
consisting of many latent variables (constructs) and many indicators, as was the case with the model herein.

\subsection{Data preparation}

From the 305 valid questionnaire responses, preliminary evaluation indicated the need to impute three missing data values in a single questionnaire. The imputation proceeded on the basis of the principle of the average of nearest neighbouring values. Initial analyses were also performed to detect multivariate outliers, using the Mahalanobis distance (Tabachnick and Fidell, 2001). The Mahalanobis test identified only three non-typical combinations in the sample, but these were evaluated as false outliers (representing atypical but real cases).

Testing for mean equivalence was necessary because the sample consisted of respondents with different roles and at hierarchical levels in the surveyed companies

i $\mathrm{CEO} /$ Superintendents

ii functional area directors

iii functional area managers

iv advisors/supervisors.

The multi-group analysis (MGA) equivalence test sought to detect whether or not the groups of respondents exhibited differences in means that could be considered statistically significant. In order to conduct MGA, it was decided to evaluate the scores of two groupings following a hierarchical principle: first Group (CEOs; General Directors; Superintendents; Area Directors) and second Group (functional area Managers and functional area Advisors/Supervisors). The results of the MGA test did not indicate equivalence problems between the means of these two groups, as significant loads of indicators were observed in the same factors for both groups of respondents.

It was also necessary to explore possible common method variance (CMV), as respondents expressed their perceptions with respect to both independent (exogenous) and dependent (endogenous) variables of the model. In addition, tests for CMV were performed based on the aim of this study to describe latent variables of complex and highly abstract phenomena. Accordingly, Harman's single factor test and the Measured Latent Marker Variable Approach (MLMV) were used to quantify CMV.

According to Harman's single factor test, exploratory factor analysis (EFA) indicated the presence of 16 factors with eigenvalues greater than 1, and none of them captured a significant part of the total variance. The first extracted factor explained only $26.13 \%$ of the total variance, thus indicating no effects that could characterise the presence of bias.

Moving on, MLMV is particularly recommended for studies using the PLS method, as it offers greater validity and reliability in the context of measurement and structural models (Tehseen et al., 2017). To meet the first requirement of this test, four latent variables were selected from the research instrument, that were not included in the research model, to form a latent marker variable:

i revenue;

ii number of SKUs 
iii number of employees

iv predominant strategic orientation (cost or differentiation).

Since these are essentially variables which describe the sample, one would not expect to find strong correlations between these variables and those latent variables that make up the measurement models in the study, unless a common variance problem was present. The test results indicated that the values for path coefficients after MLMV correction are similar to the initial results without the exogenous latent variable (marker-variable), demonstrating that CMV was not identified in this research.

\section{Sample description}

Regarding the positions held by the respondents, the sample consisted mainly of highlevel professionals: CEOs, General Directors, and Superintendents (68 cases, $22 \%$ of the sample) and functional area Directors (133 cases, $44 \%$ of the sample). The sample also consisted of functional area Managers (60 cases, 20\% of the sample) and, to a lesser extent, functional area Advisors/Supervisors (44 cases, 14\% of the sample). The fact that $86 \%$ of the sample was constituted by high-level professionals is in line with the objective of this study. Given the nature of the constructs and relationships being studied it was important that the sample should consist of respondents with highly systemic perceptions of the value chain processes of the firms. This description is summarised in Figure 2.

Figure 2 Sample description: position held by the respondents (see online version for colours)

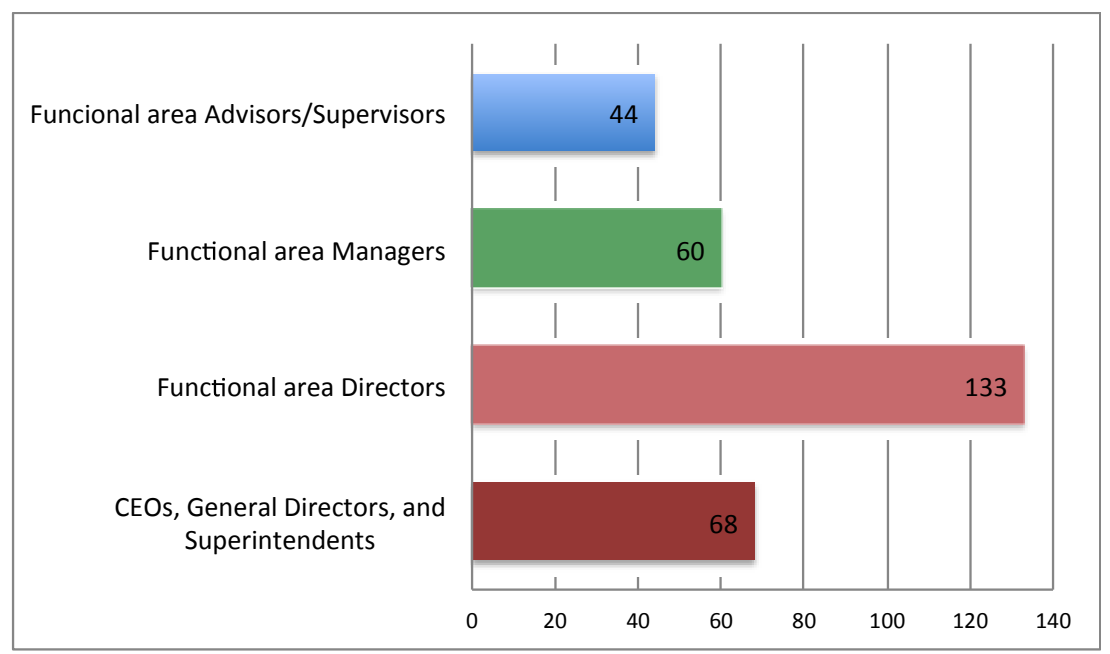

All companies in the sample are manufacturers of non-durable consumer goods: most of them are food companies (201 cases, $66 \%$ of the sample), followed by companies in the hygiene, health, and beauty products segment (29 cases, $9.5 \%$ of the sample); alcoholic and non-alcoholic beverages ( 21 cases, $7 \%$ of the sample); fashion products, clothing, and accessories (20 cases, $6.5 \%$ of the sample); and pharmaceutical products ( 9 cases, $3 \%$ 
of the sample); packaging producers, cleaning items, textiles, tobacco, and others (25 cases, $8 \%$ of the sample).

In terms of revenues, $40.3 \%$ of respondents (123 cases) stated that their companies had annual revenues over U\$ 200 million. A significant proportion of the sample $(41.3 \%$ of respondents, 126 cases) consisted of respondents who stated that their companies had annual revenues less than U\$ 70 million. Finally, 18.3\% of respondents (56 cases) stated that the annual revenue of the firms would be between U\$ 70 million and U\$ 200 million. Regarding the number of employees, $51.8 \%$ of the sample (158 cases) consisted of respondents working in companies with more than 600 employees. Of the rest of the sample, 119 respondents (39.1\%) worked in companies that had between 101 and 600 employees, and 28 respondents $(9.1 \%$ of the sample) worked in companies that had between 1 and 100 employees. Thus, taking into account the parameters of number of employees and companies' annual revenues, it can be concluded that the sample included mainly medium and large organisations and excluded small companies. This description is summarised in Figure 3.

Figure 3 Sample description: number of companies' direct employees (see online version for colours)



Another variable of interest, from the point of view of sample description, was related to the number of lines and products sold by firms. Even though this measure alone cannot express the complexity of an operations system, the number of SKUs may be related to the integration and flexibility requirements of business processes. In the present study, 204 respondents $(66.9 \%$ of the sample) reported operating in companies that produced and marketed over 100 SKUs; 59 respondents (19.3\% of the sample) reported that their companies produced and marketed between 31 and 100 SKUs; and 42 respondents (13.8\% of the sample) reported operating in firms that produced and marketed 30 or fewer SKUs.

\subsection{Measurement model results}

To test the measurement models, the protocol recommended by Hair et al. (2017) was followed. The nine first-order constructs in the model consist of 47 manifest variables. To 
verify the unidimensionality of the constructs, the Dillon-Goldstein (DG) rho test was used as the measure composite reliability, as it is considered more robust than Cronbach's alpha (Sanchez, 2013). The DG rho test results did not identify construct unidimensionality problems, with all values obtained being above the cutoff point $(0.70)$.

To test convergent validity, outer loadings, commonalities, and average variance extracted (AVE) were examined, and problems were found in five variables (INTI 7, EXIS 1, SF2, SF5, and FCOP2). Although the outer load of the INTI 7 indicator is slightly below the value of the cut-off range $(0.70)$ and has a commonality value less than 0.50 , this indicator was retained given its theoretical relevance, and therefore, its content validity. There are several studies in the literature (Kohlbacher and Gruenwald, 2011; McCormack et al., 2003; Škrinjar et al., 2008) identifying process orientation as an important condition for improving process integration levels and operations, in the context of a firm's value chain. The EXIS 1 and FCOP2 indicators were also retained due to their content validity. The SF2 and SF5 indicators were extracted from the instrument due to the low values observed for both loads and commonalities. Table 3 presents the number of items of each construct of the research model, as well as Cronbach's alpha and DG rho values obtained for each of these latent variables, after removing the two indicators mentioned.

Table 3 Unidimensionality of variable blocks

\begin{tabular}{lccc}
\hline Latent variable & Item number & Cronbach's alpha & DG rho \\
\hline PIS & 4 & 0.775 & 0.857 \\
PIC & 4 & 0.803 & 0.872 \\
INTI & 7 & 0.845 & 0.883 \\
SF & 3 & 0.716 & 0.843 \\
MF & 3 & 0.706 & 0.836 \\
DF & 5 & 0.701 & 0.807 \\
FSCA & 9 & 0.879 & 0.903 \\
FRES & 5 & 0.845 & 0.890 \\
FOP & 5 & 0.773 & 0.847 \\
\hline
\end{tabular}

PIS: process integration with key suppliers; PIC: process integration with key customers;

INTI: internal process integration; SF: source process flexibility; MF: make process

flexibility; DF: deliver process flexibility; FSCA: firm's supply chain agility; FRES:

firm's resilience; FOP: firm's overall performance.

With the purpose of evaluating convergent validity of the measurement models, the average variance extracted (AVE) of the constructs was calculated from the mean of the sum of the squares of the loads of their indicators. As a rule, variable blocks are expected to have common values above 0.50. The results are shown in Appendix A. Since all results were above 0.50 , there is convergent validity for all blocks of variables that make up the structural model of the present study.

Finally, tests were performed to evaluate the discriminant validity of the measurement models. There is discriminant validity when the load of an item that makes up a particular block of variables (construct) is higher than the loads of that item with other constructs of the structural model. The results obtained for such cross-loadings of the model indicators show that there are no discriminant validity problems in the model. 
The discriminant validity of the measurement models was assessed by evaluating the cross-loadings and the Fornell-Larcker criterion (Fornell and Larcker, 1981; Hair et al., 2017). The AVE square root values for each construct of the model were higher than the covariance values between that construct and other latent variables of the structural model, demonstrating the absence of discriminant validity problems in the model.

\subsection{Structural model results}

Path coefficients (direct effects) and indirect effects were classified in three different impact levels: effect values between 0 and 0.30 were classified as weak; values between 0.30 and 0.70 were classified as strong; values above 0.70 were rated as very strong. All structural model path coefficients were considered significant with the bootstrapping test at $p<0.0001$. All results are presented in Table 4 .

Table 4 Path coefficients for sample data and bootstrapping test

\begin{tabular}{|c|c|c|c|c|}
\hline Hypotheses & $\begin{array}{l}\text { Total } \\
\text { effects }\end{array}$ & $\begin{array}{c}\text { Path } \\
\text { coefficients }\end{array}$ & $\begin{array}{l}\text { Means with } \\
\text { bootstrap }\end{array}$ & $\begin{array}{l}\text { Hypothesis } \\
\text { confirmed? }\end{array}$ \\
\hline $\begin{array}{l}\text { H1. } \\
\text { PROCESS INTEGRATION } \rightarrow \text { FSCA }\end{array}$ & $\begin{array}{l}\text { Direct } \\
\text { effects }\end{array}$ & 0.389 & 0.379 & Yes \\
\hline $\begin{array}{l}\text { HIa. } \\
\qquad \mathrm{INTI} \rightarrow \mathrm{FSCA}\end{array}$ & $\begin{array}{l}\text { Indirect } \\
\text { effects }\end{array}$ & 0.207 & 0.203 & Yes \\
\hline $\begin{array}{l}H 1 b . \\
\qquad \mathrm{EXI} \rightarrow \mathrm{FSCA}\end{array}$ & $\begin{array}{l}\text { Indirect } \\
\text { effects }\end{array}$ & 0.217 & 0.209 & Yes \\
\hline $\begin{array}{l}\text { H2. } \\
\text { PROCESS FLEXIBILITY } \rightarrow \text { FSCA }\end{array}$ & $\begin{array}{l}\text { Direct } \\
\text { effects }\end{array}$ & 0.411 & 0.431 & Yes \\
\hline $\begin{array}{l}H 2 a . \\
\mathrm{SF} \rightarrow \mathrm{FSCA}\end{array}$ & $\begin{array}{l}\text { Indirect } \\
\text { effects }\end{array}$ & 0.124 & 0.130 & Yes \\
\hline $\begin{array}{l}\mathrm{H} 2 b . \\
\mathrm{MF} \rightarrow \mathrm{FSCA}\end{array}$ & $\begin{array}{l}\text { Indirect } \\
\text { effects }\end{array}$ & 0.152 & 0.159 & Yes \\
\hline $\begin{array}{l}\mathrm{H} 2 c . \\
\mathrm{DF} \rightarrow \mathrm{FSCA}\end{array}$ & $\begin{array}{l}\text { Indirect } \\
\text { effects }\end{array}$ & 0.225 & 0.233 & Yes \\
\hline $\begin{array}{l}\mathrm{H} 3 . \\
\text { FSCA } \rightarrow \text { FOP }\end{array}$ & $\begin{array}{l}\text { Direct } \\
\text { effects }\end{array}$ & 0.571 & 0.590 & Yes \\
\hline $\begin{array}{l}\text { H4. } \\
\text { FSCA } \rightarrow \text { FRES }\end{array}$ & $\begin{array}{l}\text { Direct } \\
\text { effects }\end{array}$ & 0.706 & 0.720 & Yes \\
\hline
\end{tabular}

INTI: internal process integration; EXI: External process integration with key suppliers and key customers; SF: source process flexibility; MF: make process flexibility; DF: deliver process flexibility; FSCA: firm's supply chain agility; FRES: firm's resilience; FOP: firm's overall performance.

In addition to path coefficients, another important parameter that should be evaluated in testing the structural model is the determination coefficients $\left(R^{2}\right)$. The magnitude of these coefficients for the model constructs showed the importance of efforts to integrate processes (internal and external) and flexibility as determinants of agility, with 
approximately $51.4 \%$ of the variation in agility being explained by these two constructs. The results also indicate a good model fit when the effects of agility on the variance in organisational resilience outcomes $\left(R^{2}=0.498\right)$ and the firm's competitive performance $\left(R^{2}=0.326\right)$ are assessed. These results are presented in Figure 4.

Figure 4 Path and structural model determination coefficients



All significant effects at $p<0.001$ when subjected to the t-test with the bootstrapping technique.

Goodness of fit (GOF) was calculated to be 0.6237 . This measure provides information on how well the sample data reflects the population of interest. There are several adjustment tests, both parametric and nonparametric. The test used in the present study took both the commonality values and the determination coefficients into consideration. Thus, GOF is a measure of the quality adjustment of both measurement models and the structural research model. In sum, this GOF of 0.6237 indicates that the validated model is robust for predicting the correlation matrix of population data.

\section{Discussion}

In line with the literature, the results of the present study confirmed the effects of process integration and flexibility on the firm's agility. A significant portion of the variation in agility, measured by the coefficient of variation $\left(R^{2}=0.514\right)$, was explained by these two variables. However, the results also suggest that the effect of flexibility on agility appears to be greater and explains most of the variance in agility. This can be observed by the 
values assumed by the path coefficients: the coefficients describing the effects of process integration and flexibility on agility were significant according to the bootstrapping test $(p<0.0001)$, with values of 0.389 and 0.411 , respectively. These values indicate that, proportionally, improvements in flexibility have significantly greater impact on agility than improvements in process integration. These results answer the first hypothesis, and show that companies need to invest in both to become more agile. However, flexibility has been identified as the main or most important antecedent of FSCA.

Regarding the positive effects of agility on organisational resilience and the competitive performance of firms, the results herein corroborate findings from previous studies, with high and statistically significant values for the path coefficients of the firm's supply chain and organisational resilience (FRES, 0.706); and, the firm's supply chain agility and competitive performance (FOP, 0.571). These coefficients indicate the expected increase in the firm's resilience and competitive performance due to unitary changes in agility. The results found for the determination coefficients were also significant, with $49.8 \%$ of resilience variation and $32.6 \%$ of firm performance variation being explained by agility. These findings corroborate evidence from previous empirical studies and respond to the second hypothesis raised in the present study (Christopher, 2005; Christopher and Peck, 2004; Gligor et al., 2015; Van Hoek et al., 2001; Naylor et al., 1999; Pettit et al., 2013; Ponomarov and Holcomb, 2009; Swafford et al., 2008).

In summary, the validated structural model indicates the existence of a nomological network of effects, showing that the most agile firms are also the most apt to cope with and overcome (with the lowest possible cost and time penalty) disruptive events, in the operations of firms and supply chains. Future studies may detail how or by what means, and under what conditions, agility affects the firm's level of resilience and competitive performance. In addition, the present study did not identify resilience as a performance antecedent. However, further studies may shed more light on the issue by assessing whether there is a precedence relationship among constructs, or even whether resilience exerts a moderating or even mediating effect on the relationship between agility and performance.

Although the results of the present study are robust, and have been validated by a large sample of key informants and companies, these findings must be taken with caution. In Wieland and Wallenburg (2013), for example, a study of small, medium, and large industrial companies with operations in Germany, Austria, and Switzerland, observed that the association between process integration and resilience was not very strong. These findings were presented as evidence that the integration of processes (especially external) may paradoxically serve to restrict (inhibit) the firm's intensity and reaction rate in turmoil times. This is just the opposite of what would be expected in response to uncertainties and dynamics of complex, turbulent, and intensely competitive scenarios.

In line with other studies, such as those by Manuj and Mentzer (2008) and Norrman and Jansson (2004), it is possible to assume that the level of integration of the firm's external processes with its suppliers and direct clients would be related to the level of dependence, and the frequency of risk events that may be faced by the contractor. This is the case, for example, in relationships where the presence of investments in specific assets (such as equipment, facilities, and people) is perceived, and where such investments end up influencing the decisions and conduct of economic agents. The presence of specific assets in a transaction encourages more exclusive forms of partnerships and contracts, moving firms away from the intrinsic logic of pure 
competition in the form of market governance. Thus, if on the one hand more exclusive relationships, in partnerships, require greater integration of business processes between supplier and contractor, on the other hand they may increase the risk of disruption of the contractor's external processes, restricting the number of business options, possible changes or reconfigurations of resources, and this may be reflected in a reduction in the firm's level of flexibility (Hagedoorn and Hesen, 2007; Hald et al., 2009; Koste et al., 2004). Future studies may shed light on this issue and indicate more clearly whether, and at what level, the integration of internal and external business processes would restrict the firm's degree of flexibility.

Following the perceptions of the key informants in the present study, it can be observed that firms' efforts to increase the integration of their internal processes seem to be accompanied by an orientation towards the integration of their external processes in relation to the value flows with strategic suppliers (PIS; $r=0.626$ ) and with strategic customers (PIC; $r=0.582$ ). These findings corroborate findings from previous studies, demonstrating that business process management orientation promotes a more systemic, less fragmented, and less functionally oriented approach, and is highly effective at improving the management of value streams in the context of firms' supply chains (Bergh et al., 2012; Doebeli et al., 2011; Kohlbacher, 2010; Kohlbacher and Gruenwald, 2011; McCormack et al., 2009; Prajogo et al., 2016; Zhao et al., 2011).

In the form of indirect effects, the survey data indicated that internal and external process integration was positively associated with the firm's resilience level $(r=0.613)$ and, to a lesser extent, with the firm's performance $(r=0.471)$. Even though there is no expression of a causal relationship among the variables here, as these are indirect effects, these findings corroborate findings from other research. Studies have shown, for example, the predictive effect of process integration on the firm's performance, as well as the role of integration as an absorptive capability of the firm, are important for learning from external partners and for better coordination of upstream and downstream flows with these agents (Flynn et al., 2010; Hillebrand and Biemans, 2004; Lane et al., 2006; Takeishi, 2001).

The survey findings showed a positive and moderate association between the dimensions of flexibility and performance $(r=0.488)$, and a slightly stronger association between the dimensions of flexibility and organisational resilience $(r=0.677)$. Noting that there are already studies in the literature which have explored the relationship between flexibility and performance, further research may focus primarily on investigating the effects of flexibility on resilience. This study's contributions can be used to define operational variables for this research agenda.

The present study has several contributions. One of the contributions is to provide evidence that the predictive effects of integration and flexibility on a firm's agility can only be fully explained if we adopt a perspective of analysis that goes beyond the firm's efficiency limit, and necessarily incorporates the effectiveness of upstream and downstream flows of the focal firm. In addition, the present study provides empirical evidence that process integration and flexibility are important constraints on supply chain agility and, consequently, have significant potential to leverage better competitive performance outcomes and, especially, to develop better conditions for firms to be more resilient. In volatile, uncertain, complex, and ambiguous (VUCA) times, agility is a survival condition for companies to move quickly, handle high levels of complexity and, in line with the words of GSK Executive Vice President for Human Resources, 
Meenakshi Priyam, “... the real agility is when you proactively create value...” (Modgil, 2018).

This study has positioned agility in a broader perspective of the firm, taking into account the respondents' perception of the firm's internal efficiency limits as well as the upstream and downstream value chains. In this sense, it extends previous research that considers agility in this same context (FSCA) by investigating the simultaneous effects of process integration and flexibility on agility. Another relevant aspect is that we have found out that a large part of the variation in the firm's resilience was explained by agility levels. Therefore, this research extends previous recent studies by characterising the indirect effects process integration and flexibility have on resilience.

The COVID-19 pandemic has caused vast economic breakdown worldwide, since production and economic activities have been partially or totally interrupted in several areas with implications never seen before (Rapaccini et al., 2020). As the virus spread across the globe, its impact on industries and individual firms became more apparent, with many nations coming to lock-downs and closing of borders, increasing uncertainty. Researchers recommend managers should have a holistic view in terms of uncertainty to ensure a more unified approach to dealing with such global disasters in future (Sharma et al., 2020).

Due to such unprecedent impacts, research on resilience and agility specially in some types of supply chains (pharmaceutical, grocery retailers, and the healthcare and safety sectors) should increase since they are critical for society and require specific attention from government (de Sousa Jabbour et al., 2020). As so, supply chains should display the ability of being flexible and agile and executives need to focus on making the necessary adjustments to their operations in order to survive this pandemic (Yost, 2020). Crate and Barrel's CEO, for instance, believes that the need for more agile decision making is of the long-lasting repercussions for organisation of the COVID-19 pandemic (Slaughter, 2020). Although this study's data were collected a few months before the spatio-temporal propagation of the first wave of the COVID-19, we believe the outcomes of this research will be even more important due to current context and demands.

Another contribution of the present study is that it has validated a theoretical model that sought to reduce ambiguities and inconsistencies in the use of the concepts of flexibility and agility. Such concepts, although distinct, can sometimes be treated as interchangeable. This is a problem found by different researchers (Backhouse and Burns, 1999; Bernardes and Hanna, 2009; Goldman et al., 1994; Upton, 1994, 1997; Wadhwa and Rao, 2003).

\subsection{Limitations}

The orientation of the present study, to explore the phenomenon of agility following the perspective of firms' value chains, certainly led to some abstraction in the determination of concepts and added greater complexity to data analysis, considering the subtleties and particularities of the associations among the constructs that make up the structural model.

It must also be considered that the data collection took place using self-administered questionnaires, made available electronically to key informants in strategic positions in the companies participating in the study. Even though the sample consisted of highranking agents of these firms, with a comprehensive view of the business, nothing 
changes the fact that the data reflect the individual perceptions of these respondents. Even though specific tests to identify biases derived from the method employed herein, such as CMV, were performed and the possibility of biases was ruled out, it is still important to emphasise that these data are subjective by definition.

Finally, the present study relied on a quantitative approach without incorporating qualitative methods or instruments for prospecting and analysing empirical data. Although the survey instrument met certain formal prerequisites (clear introduction and detailed instructions for respondents; consistency in terms of page layout and answer fields; appropriately structured questions in terms of length and syntax) and was constructed based on a broad literature review, the incorporation of other data collection techniques could have been beneficial. Interviews and direct observations could have brought out subtleties and finer perceptions about the phenomenon investigated, extending the limits of its description and analysis.

\section{Conclusions}

This research sought to identify the antecedents of firm's supply chain agility and the effects over organisational resilience and overall performance of industrial firms. A total number of 305 top executive and professional managers were surveyed, working on different industrial segments of non-durable consumer goods manufacturing. This is a sector in which firms face unprecedented technological dynamism, intense competition, and increased vulnerabilities and risks of disruption in complex supply chains, including different economic players such as wholesalers, retailers, transportation, and logistics companies, as well as final direct customers.

The predictive effects of value chain process integration and flexibility over agility were described and validated, as well as the impact of agility on organisational resilience and firm's overall performance. An important and distinctive aspect of our conceptual model, comparing our work with others already done on the subject, is that it uses a value chain perspective to investigate the effects of integration and flexibility on firm's agility. We understand that the findings of this study assume both practical and theoretical relevance, by allowing the identification of improvements paths for a greater effectiveness of operations, in a value chain context.

The outcomes of this study will be of greater interest to the research community. The current situation of the Covid-19 pandemic in the world demands greater agility, ability to work in changing contexts and to redesign the supply chains.

Considering the current context and the potential effects of agility on organisational resilience and performance, we expect that leaders with a broad and strategic vision are motivated to lead the necessary transformations in their organisations, so that the agile culture can flourish. These leaders should challenge the assumptions of rigid, bureaucratic and hierarchical structures, since higher levels of agility require reduced hierarchical levels and less rigid functional division. Finally, firms should also decisively embrace a broader view of principles, capabilities and practices for the benefit of greater flexibility in source, make and deliver process areas, tested in our research as important antecedents of firms supply chain agility. 


\section{References}

Akter, S., Fosso, S., Gunasekaran, A., Dubey, R. and Childe, S.J. (2016) 'How to improve firm performance using big data analytics capability and business strategy alignment?', International Journal of Production Economics, Vol. 182, pp.113-131, https://doi.org/ 10.1016/j.ijpe.2016.08.018

APICS (2017) 'SCOR model - quick reference guide', Supply Chain Operations Reference Model (SCOR) - Quick Reference Guide, apics.org/scor.

Ashrafi, A., Zare Ravasan, A., Trkman, P. and Afshari, S. (2019) 'The role of business analytics capabilities in bolstering firms' agility and performance', International Journal of Information Management, Vol. 47, July 2018, pp.1-15, https://doi.org/10.1016/j.ijinfomgt.2018.12.005

Backhouse, C.J. and Burns, N.D. (1999) 'Agile value chains for manufacturing: implications for performance measures', International Journal of Agile Management Systems, Vol. 1, No. 2, pp.76-82, https://doi.org/https://doi.org/10.1108/14654659910280893

Bergh, J.V., Thijs, S., Isik, Ö. and Viaene, S. (2012) 'The world is not enough: customer centricity and processes', BPTrends, pp.1-6.

Bernardes, E. and Hanna, M.D. (2009) 'A theoretical review of flexibility, agility and responsiveness in the operations management literature', International Journal of Operations and Production Management, Vol. 29, No. 1, pp.30-53, https://doi.org/10.1108/014435 70910925352

Blome, C., Schoenherr, T. and Rexhausen, D. (2013) 'Antecedents and enablers of supply chain agility and its effect on performance: a dynamic capabilities perspective', International Journal of Production Research, Vol. 51, No. 4, pp.1295-1318, https://doi.org/10.1080/0020 7543.2012.728011

Braunscheidel, M.J. and Suresh, N.C. (2009) 'The organizational antecedents of a firm's supply chain agility for risk mitigation and response', Journal of Operations Management, Vol. 27, No. 2, pp.119-140, https://doi.org/10.1016/j.jom.2008.09.006

Bronzo, M., de Resende, P.T.V., de Oliveira, M.P.V., McCormack, K.P., de Sousa, P.R. and Ferreira, R.L. (2013) 'Improving performance aligning business analytics with process orientation', International Journal of Information Management, Vol. 33, No. 2, pp.300-307, https://doi.org/10.1016/j.ijinfomgt.2012.11.011

Chen, H., Daugherty, P.J. and Landry, T.D. (2009) 'Supply chain process integration: a theoretical framework', Journal of Business Logistics, Vol. 30, No. 2, pp.27-46, https://doi.org/ https://doi.org/10.1002/j.2158-1592.2009.tb00110.x

Christopher, M. (2000) 'The agile supply chain: competing in volatile markets', Industrial Marketing Management, Vol. 29, No. 1, pp.37-44, https://doi.org/https://doi.org/10.1016/ S0019-8501(99)00110-8

Christopher, M. (2005) 'Managing risk in the supply chain', Logistics and Supply Chain Management , pp.231-258.

Christopher, M. and Peck, H. (2004) 'Building the resilient supply chain', in The International Journal of Logistics Management, Vol. 15, No. 2, https://doi.org/10.1108/09574090 410700275, pp.1-13.

Christopher, M. and Towill, D. (2001) 'An integrated model for the design of agile supply chains', International Journal of Physical Distribution and Logistics Management, Vol. 31, No. 4, pp.235-246, https://doi.org/10.1108/09600030110394914

Colicchia, C. and Strozzi, F. (2012) 'Supply chain risk management: a new methodology for a systematic literature review', Supply Chain Management: An International Journal, Vol. 17, No. 4, pp.403-418, https://doi.org/https://doi.org/10.1108/13598541211246558

Cosgrove, E. (2020) Unilever CSCO: Agility Beats Forecasting When the Supply Chain is Stressed, SUPPLYCHAINDIVE.

Craighead, C.W., Blackhurst, J., Rungtusanatham, M.J. and Handfield, R.B. (2007) 'The severity of supply chain disruptions: design characteristics and mitigation capabilities', Decision Sciences, Vol. 38, No. 1, pp.131-156, https://doi.org/10.1111/j.1540-5915.2007.00151.x 
de Sousa Jabbour, A.B.L., Jabbour, C.J.C., Hingley, M., Vilalta-Perdomo, E.L., Ramsden, G. and Twigg, D. (2020) 'Sustainability of supply chains in the wake of the coronavirus (COVID19/SARS-CoV-2) pandemic: lessons and trends', Modern Supply Chain Research and Applications, Ahead-of-print (ahead-of-print), https://doi.org/10.1108/mscra-05-2020-0011

Doebeli, G., Fisher, R., Gapp, R. and Sanzogni, L. (2011) 'Using BPM governance to align systems and practice', Business Process Management Journal, Vol. 17, No. 2, pp.184-202, https://doi.org/10.1108/14637151111122310

Dubey, R., Ali, S.S., Aital, P. and Venkatesh, V. (2014) 'Mechanisms of humanitarian supply chain agility and resilience and its empirical validation', International Journal of Services and Operations Management, Vol. 14, No. 4, pp.367-384, https://doi.org/https://doi.org/10.1504/ IJSOM.2014.059999

Dubey, R., Gunasekaran, A., Blome, C., Papadopoulos, T. and Childe, S.J. (2018) 'Supply chain agility, adaptability and alignment: empirical evidence from the Indian auto components industry', International Journal of Operations and Production Management, Vol. 38, No. 1, pp.129-148, https://doi.org/https://doi.org/10.1108/IJOPM-04-2016-0173

Dyer, J. and Singh, H. (1998) 'The relational view: cooperative strategy and sources of interorganizational competitive strategy', The Academy of Management Review, Vol. 23, No. 4, pp.660-679, https://doi.org/10.2307/259056

Flynn, B.B., Huo, B. and Zhao, X. (2010) 'The impact of supply chain integration on performance: a contingency and configuration approach', Journal of Operations Management, Vol. 28, pp.58-71, https://doi.org/https://doi.org/10.1016/j.jom.2009.06.001

Fornell, C. and Larcker, D.F. (1981) 'Evaluating structural equation models with unobservable variables and measurement error', Journal of Marketing Research, Vol. 18, No. 1, pp.39-50, https://doi.org/10.2307/3151312

Frohlich, M.T. and Westbrook, R. (2002) 'Demand chain management in manufacturing and services: web-based integration, drivers and performance', Journal of Operations Management, Vol. 20, No. 6, pp.729-745, https://doi.org/https://doi.org/10.1016/S02726963(02)00037-2

Gligor, D.M. (2018) 'Performance implications of the fit between supplier',s 'flexibility and their customers' expected flexibility: a dyadic examination', Journal of Operations Management, Vols. 58-59, pp.73-85, https://doi.org/10.1016/j.jom.2018.05.002

Gligor, D.M., Esmark, C.L. and Holcomb, M.C. (2015) 'Performance outcomes of supply chain agility: when should you be agile?', Journal of Operations Management, Vols. 33-34, pp.71-82, https://doi.org/10.1016/j.jom.2014.10.008

Goldman, S.L., Nagel, R.N. and Preiss, K. (1994) Agile Competitors and Virtual Organizations: Strategies for Enriching the Customer (V. Reinhold,N. (ed.)).

Grewal, R. and Tansuhaj, P. (2001) 'Building organizational capabilities for managing economic crisis: the role of market orientation and strategic flexibility', Journal of Marketing, Vol. 65, No. 2, pp.67-80, https://doi.org/https://doi.org/10.1509/jmkg.65.2.67.18259

Gunasekaran, A. and Yusuf, Y. (2002) 'Agile manufacturing: a taxonomy of strategic and technological imperatives', International Journal of Production Research, Vol. 40, No. 6, pp.1357-1385, https://doi.org/10.1080/00207540110118370

Gupta, Y.P. and Sommers, T.M. (1992) 'The measurement of manufacturing flexibility', European Journal of Operational Research, Vol. 60, pp.166-182, https://doi.org/https://doi.org/10.1016/ 0377-2217(92)90091-M

Hagedoorn, J. and Hesen, G. (2007) 'Contract law and the governance of inter-firm technology partnerships - an analysis of different modes of partnership and their contractual implications', Journal of Management Studies, Vol. 44, No. 3, pp.343-366, https://doi. org/https://doi.org/10.1111/j.1467-6486.2006.00679.x

Hair, J.F., Hult, G.T.M., Ringle, C.M. and Sarstedt, M. (2017). A Primer on Partial Least Squares Structural Equation Modeling (PLS-SEM), (S. P. Inc. (ed.); 2nd ed.). 
Hald, K.S., Cordón, C. and Vollmann, T. (2009) 'Towards an understanding of attraction in buyersupplier relationships', Industrial Marketing Management, Vol. 38, No. 8, pp.960-970, https://doi.org/https://doi.org/10.1016/j.indmarman.2008.04.015

Haq, A.N. and Boddu, V. (2015) 'Analysis of agile supply chain enablers for Indian food processing industries using analytical hierarchy process', International Journal of Manufacturing Technology and Management, Vol. 29, Nos. 1-2, pp.30-47, https://doi.org/10. 1504/IJMTM.2015.066780

Hillebrand B. and Biemans, W.G. (2004) 'Links between internal and external cooperation in product development: an exploratory study', Journal of Production Innovation Management, Vol. 21, No. 2, pp.110-122, https://doi.org/https://doi.org/10.1111/j.0737-6782.2004.00061.x

Jüttner, U. and Maklan, S. (2011) 'Supply chain resilience in the global financial crisis: an empirical study', Supply Chain Management: An International Journal, Vol. 16, No. 4, pp.246-259, https://doi.org/10.1108/13598541111139062

Kohlbacher, M. (2010) 'The effects of process orientation: a literature review', Business Process Management Journal, Vol. 16, No. 1, pp.135-152, https://doi.org/10.1108/14637151011 017985

Kohlbacher, M. and Gruenwald, S. (2011) 'Process orientation: conceptualization and measurement', Business Process Management Journal, Vol. 17, No. 2, pp.267-283, https://doi.org/10.1108/14637151111122347

Koste, L.L., Malhotra, M.K. and Sharma, S. (2004) 'Measuring dimensions of manufacturing flexibility', Journal of Operations Management, Vol. 22, No. 2, pp.171-196, https://doi.org/ https://doi.org/10.1016/j.jom.2004.01.001

KPMG (2019) Agile or Irrelevant: Redefining Resilience, Retrieved 21 June, from https://assets.kpmg/content/dam/kpmg/us/pdf/2019/06/2019-ceo-outlook.pdf

Lane, P.J., Koka, B.R. and Pathak, S. (2006) 'The reification of absorptive capacity: a critical review and rejuvenation of the construct', The Academy of Management Review, Vol. 31, No. 4, pp.833-863, https://doi.org/10.2307/20159255

Lockamy, A. and McCormack, K. (2004) 'The development of a supply chain management process maturity model using the concepts of business process orientation', Supply Chain Management: An International Journal, Vol. 9, No. 4, pp.272-278.

Manuj, I. and Mentzer, J.T. (2008) 'Global supply chain risk management strategies', International Journal of Physical Distribution and Logistics Management, Vol. 38, No. 3, pp.192-223, https://doi.org/https://doi.org/10.1108/09600030810866986

Matawale, C.R., Datta, S. and Mahapatra, S.S. (2015) 'Evaluation of leanness, agility and leagility for supply chain of automotive industries', International Journal of Agile Systems and Management, Vol. 8, No. 2, pp.85-115, https://doi.org/10.1504/Ijasm.2015.070603

McCormack, K., Willems, J., van den Bergh, J., Deschoolmeester, D., Willaert, P., Štemberger, M.I., Škrinjar, R., Trkman, P., Ladeira, M.B., de Oliveira, M.P.V., Vuksic, V.B. and Vlahovic, N. (2009) 'A global investigation of key turning points in business process maturity', Business Process Management Journal, Vol. 15, No. 5, pp.792-815, https://doi.org/10.1108/1463715 0910987946

McCormack, K.P., Johnson, W.C. and Walker, W. (2003) Supply Chain Networks and Business Process Orientation: Advanced Strategies and Best Practices (A. S. on R. Management (ed.)), CRC Press.

Modgil, G. (2018) Real Agility is When You Proactively Create Value, Retrieved 21 June, from https://www.peoplematters.in/article/culture/our-issue-is-not-about-the-number-of-peoplewho-are-young-but-people-who-are-employable-meenakshi-priyam-gsk-19475

Mustafid, Karimariza, S.A. and Jie, F. (2018) 'Supply chain agility information systems with key factors for fashion industry competitiveness', International Journal of Agile Systems and Management, Vol. 11, No. 1, pp.1-22, https://doi.org/10.1504/ijasm.2018.091352 
Naylor, J.B., Naim, M.M. and Berry, D. (1999) 'Leagility: Integrating the lean and agile manufacturing paradigms in the total supply chain', International Journal of Production Economics, Vol. 62, Nos. 1-2, pp.107-118, https://doi.org/https://doi.org/10.1016/S09255273(98)00223-0

Norrman, A. and Jansson, U. (2004) 'Ericsson's proactive supply chain risk management approach after a serious sub-supplier accident', International Journal of Physical Distribution and Logistics Management, Vol. 34, No. 5, pp.434-456, https://doi.org/10.1108/0960003 0410545463

Pereira, C.R., Christopher, M. and da Silva, A.L. (2014) 'Achieving supply chain resilience: the role of procurement', Supply Chain Management, Vol. 19, Nos. 5-6, pp.626-642, https://doi.org/https://doi.org/10.1108/SCM-09-2013-0346

Pettit, T.J., Croxton, K.L. and Fiksel, J. (2013) 'Ensuring supply chain resilience: development and implementation of an assessment tool', Journal of Business Logistics, Vol. 34, No. 1, pp.46-76, https://doi.org/10.1111/jbl.12009

Ponomarov, S.Y. (2012) Antecedents and Consequences of Supply Chain Resilience : A Dynamic Capabilities Perspective, University of Tennesse.

Ponomarov, S.Y. and Holcomb, M.C. (2009) 'Understanding the concept of supply chain resilience', The International Journal of Logistics Management, Vol. 20, No. 1, pp.124-143, https://doi.org/10.1108/09574090910954873

Prajogo, D., Oke, A. and Olhager, J. (2016) 'Supply chain processes: linking supply logistics integration, supply performance, lean processes and competitive performance', International Journal of Operations and Production Management, Vol. 36, No. 2, pp.220-238, https://doi.org/https://doi.org/10.1108/IJOPM-03-2014-0129

$\mathrm{R}$ Core Team (2016) $R$ : A Language and Environment for Statistical Computing (3.3.2) R Foundation for Statistical Computing.

Rapaccini, M., Saccani, N., Kowalkowski, C., Paiola, M. and Adrodegari, F. (2020) 'Navigating disruptive crises through service-led growth: the impact of COVID-19 on Italian manufacturing firms', Industrial Marketing Management, Vol. 88, May, pp.225-237, https://doi.org/10.1016/j.indmarman.2020.05.017

Rodrigues, A.M., Stank, T.P. and Lynch, D.F. (2004) 'Linking strategy, structure, process, and performance in integrated logistics', Journal of Business Logistics, Vol. 25, No. 2, pp.65-94, https://doi.org/https://doi.org/10.1002/j.2158-1592.2004.tb00182.x

Sanchez, G. (2013) PLS Path Modeling with $R$ (T. Editions (ed.)), http://www. gastonsanchez.com/PLS Path Modeling with R.pdf

Scholten, K. and Schilder, S. (2015) 'The role of collaboration in supply chain resilience', Supply Chain Management: An International Journal, Vol. 20, No. 4, pp.471-484, https://doi.org/10. 1108/SCM-11-2014-0386

Sethi, A.K. and Sethi, S.P. (1990) 'Flexibility in manufacturing: a survey', International Journal of Flexible Manufacturing Systems Volume, Vol. 2, pp.289-328, https://doi.org/https://doi.org/ 10.1007/BF00186471

Sharifi, H. and Zhang, Z. (1999) 'Methodology for achieving agility in manufacturing organisations: an introduction', International Journal of Production Economics, Vol. 62, No. 1, pp.7-22, https://doi.org/10.1016/S0925-5273(98)00217-5

Sharma, P., Leung, T.Y., Kingshott, R.P.J., Davcik, N.S. and Cardinali, S. (2020) 'Managing uncertainty during a global pandemic: an international business perspective', Journal of Business Research, Vol. 116, May, pp.188-192, https://doi.org/10.1016/j.jbusres.2020.05.026

Škrinjar, R., Bosilj-Vukšic, V. and Indihar-Štemberger, M. (2008) 'The impact of business process orientation on financial and non-financial performance', Business Process Management Journal, Vol. 14, No. 5, pp.738-754, https://doi.org/10.1108/14637150810903084

Slack, N. (1983) 'Flexibility as a manufacturing objective', International Journal of Operations and Production Management, Vol. 3, No. 3, pp.4-13, https://doi.org/10.1108/eb054696 
Slack, N. (1987) 'The flexibility of manufacturing systems', International Journal of Operations and Production Management, Vol. 7, No. 4, pp.35-45, https://doi.org/https://doi.org/ $10.1108 / \mathrm{eb} 054798$

Slack, N. (1991) The Manufacturing Advantage: Achieving Competitive Manufacturing Operations, Mercury.

Slaughter, P. (2020) Crate and Barrel CEO on Managing Through COVID-19, Brands and Marketing, https://www.hometextilestoday.com/brands-amp-marketing/crate-and-barrel-ceoon-managing-through-covid-10/

Stevenson, M. and Spring, M. (2007) 'Flexibility from a supply chain flexibility perspective : definition and review', International Journal of Operations and Production Management, Vol. 27, No. 7, pp.685-713, https://doi.org/10.1108/01443570710756956

Swafford, P.M., Ghosh, S. and Murthy, N. (2006a) 'The antecedents of supply chain agility of a firm: scale development and model testing', Journal of Operations Management, Vol. 24, No. 2, pp.170-188, https://doi.org/10.1016/j.jom.2005.05.002

Swafford, P.M., Ghosh, S. and Murthy, N. (2008) 'Achieving supply chain agility through IT integration and flexibility', International Journal of Production Economics, Vol. 116, No. 2, pp.288-297, https://doi.org/10.1016/j.ijpe.2008.09.002

Swafford, P.M., Ghosh, S. and Murthy, N.N. (2006b) 'A framework for assessing value chain agility', International Journal of Operations and Production Management, Vol. 26, Nos. 1-2, pp.118-140, https://doi.org/https://doi.org/10.1108/01443570610641639

Tabachnick, B.G. and Fidell, L.S. (2001) Using Multivariate Statistics, 4th ed., Allyn and Bacon.

Takeishi, A. (2001) 'Bridging inter-and intra-firm boundaries: management of supplier involvement in automobile product development', Strategic Management Journal, Vol. 22, No. 5, pp.403-433, https://doi.org/https://doi.org/10.1002/smj.164

Teece, D.J. (2007) 'Explicating dynamic capabilities: the nature and microfoundations of (sustainable) enterprise performance', Strategic Management Journal, Vol. 28, pp.1319-1350, https://doi.org/10.1002/smj

Teece, D.J., Pisano, G. and Shuen, A. (1997) 'Dynamic capabilities and strategic management', Strategic Management Journal, Vol. 17, No. 7, pp.509-533.

Tehseen, S., Ramayah, T. and Sajilan, S. (2017) 'Testing and controlling for common method variance: a review of available methods', Journal of Management Sciences, Vol. 4, No. 2, pp.142-168, https://doi.org/10.20547/jms.2014.1704202

Trkman, P., McCormack, K., de Oliveira, M.P.V. and Ladeira, M.B. (2010) 'The impact of business analytics on supply chain performance', Decision Support Systems, Vol. 49, No. 3, pp.318-327, https://doi.org/10.1016/j.dss.2010.03.007

Trkman, P., Stemberger, M.I., Jaklic, J. and Groznik, A. (2007) 'Process approach to supply chain integration', Supply Chain Management: An International Journal, Vol. 12, No. 2, pp.116-128, https://doi.org/10.1108/13598540710737307

Upton, D.M. (1994) 'The management of manufacturing flexibility', California Management Review, Vol. 36, No. 2, pp.72-89, https://doi.org/10.2307/41165745

Upton, D.M. (1995) 'What really makes factories flexible?', Harvard Business Review, July-August, pp.74-84.

Upton, D.M. (1997) 'Process range in manufacturing: an empirical study of flexibility', Management Science, Vol. 43, No. 8, pp.1079-1093, https://doi.org/https://doi.org/10.1287/ mnsc.43.8.1079

Van Hoek, R.I., Harrison, A. and Christopher, M. (2001) 'Measuring agile capabilities in the supply chain', International Journal of Operations and Production Management, Vol. 21, Nos. 1-2, pp.126-147, https://doi.org/10.1108/01443570110358495

Vázquez-Bustelo, D. and Avella, L. (2006) 'Agile manufacturing: industrial case studies in Spain', Technovation, Vol. 26, No. 10, pp.1147-1161, https://doi.org/10.1016/j.technovation. 2005.11.006 
Wadhwa, S. and Rao, K.S. (2003) 'Enterprise modeling of supply chains involving multiple entity flows: the role of flexibility in enhancing lead time performance', SIC, Vol. 12, No. 1, pp.1-16.

Wieland A. and Wallenburg, C.M. (2013) 'The influence of relational competencies on supply chain resilience: a relational view', International Journal of Physical Distribution and Logistics Management, Vol. 43, No. 4, pp.300-320, https://doi.org/10.1108/Ijpdlm-08-20120243

Willaert, P., Van den Bergh, J., Willems, J. and Deschoolmeester, D. (2007) 'The process-oriented organisation: a holistic view developing a framework for business process orientation maturity', Business Process Management: 5th International Conference, BPM. 2007. Proceedings, Brisbane, Australia, 24-28 September, Springer, https://doi.org/10.1007/978-3540-75183-0_1, pp.1-15

Yost, R. (2020) COVID-19 Has Rewritten Best Practices for Supply Chain, Supply Chain Brain, https://www.supplychainbrain.com/blogs/1-think-tank/post/31298-covid-19-rewrites-bestpractices-for-supply-chain

Yusuf, Y.Y., Gunasekaran, A., Musa, A., Dauda, M., El-Berishy, N.M. and Cang, S. (2014) 'A relational study of supply chain agility, competitiveness and business performance in the oil and gas industry', International Journal of Production Economics, Vol. 147, pp.531-543, https://doi.org/https://doi.org/10.1016/j.ijpe.2012.10.009

Zhang, D.Z. (2011) 'Towards theory building in agile manufacturing strategies-case studies of an agility taxonomy', International Journal of Production Economics, Vol. 131, No. 1, pp.303-312, https://doi.org/10.1016/j.ijpe.2010.08.010

Zhang, Q., Vonderembse, M.A. and Lim, J.S. (2002) 'Value chain flexibility: a dichotomy of competence and capability', International Journal of Production Research, Vol. 40, No. 3, pp.561-583, https://doi.org/https://doi.org/10.1080/00207540110091695

Zhao, X., Huo, B., Selen, W. and Yeung, J.H.Y. (2011) 'The impact of internal integration and relationship commitment on external integration', Journal of Operations Management, Vol. 29, Nos. 1-2, pp.17-32, https://doi.org/10.1016/j.jom.2010.04.004

Zollo, M. and Winter, S.G. (2002) 'Deliberate learning and the evolution of dynamic capabilities', Organization Science, Vol. 13, No. 3, pp.339-351, https://doi.org/dx.doi.org/ 10.1287/orsc. 13.3.339.2780

Appendix A: Loadings, composite reliabilities, and AVE

\begin{tabular}{lcccc}
\hline Construct & Item & Loadings & Composite reliability & AVE \\
\hline Internal process & INTI1 & 0.708 & 0.883 & 0.549 \\
integration & INTI2 & 0.767 & & \\
& INTI3 & 0.751 & & \\
& INTI4 & 0.777 & & \\
& INTI5 & 0.801 & & 0.608 \\
& INTI6 & 0.715 & & \\
Process integration & INTI7 & 0.655 & & \\
with key suppliers & PIS1 & 0.608 & 0.857 & \\
& PIS2 & 0.818 & & \\
& PIS3 & 0.821 & & \\
& PIS4 & 0.851 & & \\
\hline
\end{tabular}


Appendix A: Loadings, composite reliabilities, and AVE (continued)

\begin{tabular}{|c|c|c|c|c|}
\hline Construct & Item & Loadings & Composite reliability & $A V E$ \\
\hline \multirow{4}{*}{$\begin{array}{l}\text { Process integration } \\
\text { with key customers }\end{array}$} & PIC1 & 0.797 & \multirow[t]{4}{*}{0.872} & \multirow[t]{4}{*}{0.651} \\
\hline & PIC2 & 0.767 & & \\
\hline & PIC3 & 0.817 & & \\
\hline & PIC4 & 0.844 & & \\
\hline \multirow{5}{*}{$\begin{array}{l}\text { Source process } \\
\text { flexibility }\end{array}$} & SF1 & 0.649 & \multirow[t]{5}{*}{0.843} & \multirow[t]{5}{*}{0.689} \\
\hline & SF2 & 0.550 & & \\
\hline & SF3 & 0.910 & & \\
\hline & SF4 & 0.904 & & \\
\hline & SF5 & 0.535 & & \\
\hline \multirow{3}{*}{$\begin{array}{l}\text { Make process } \\
\text { flexibility }\end{array}$} & MF1 & 0.848 & \multirow[t]{3}{*}{0.836} & \multirow[t]{3}{*}{0.645} \\
\hline & MF2 & 0.789 & & \\
\hline & MF3 & 0.772 & & \\
\hline \multirow{5}{*}{$\begin{array}{l}\text { Deliver process } \\
\text { flexibility }\end{array}$} & DF1 & 0.737 & \multirow[t]{5}{*}{0.807} & \multirow[t]{5}{*}{0.582} \\
\hline & DF2 & 0.777 & & \\
\hline & DF3 & 0.717 & & \\
\hline & DF4 & 0.810 & & \\
\hline & DF5 & 0.772 & & \\
\hline \multirow{9}{*}{$\begin{array}{l}\text { Firm's supply } \\
\text { chain agility }\end{array}$} & FSCA1 & 0.795 & \multirow[t]{9}{*}{0.903} & \multirow[t]{9}{*}{0.575} \\
\hline & FSCA2 & 0.778 & & \\
\hline & FSCA3 & 0.699 & & \\
\hline & FSCA4 & 0.802 & & \\
\hline & FSCA5 & 0.824 & & \\
\hline & FSCA6 & 0.769 & & \\
\hline & FSCA7 & 0.704 & & \\
\hline & FSCA8 & 0.729 & & \\
\hline & FSCA9 & 0.710 & & \\
\hline \multirow[t]{5}{*}{ Firm's resilience } & FRES1 & 0.829 & \multirow[t]{5}{*}{0.890} & \multirow[t]{5}{*}{0.672} \\
\hline & FRES2 & 0.826 & & \\
\hline & FRES3 & 0.899 & & \\
\hline & FRES4 & 0.822 & & \\
\hline & FRES5 & 0.711 & & \\
\hline \multirow{5}{*}{$\begin{array}{l}\text { Firm's overall } \\
\text { performance }\end{array}$} & FOP1 & 0.680 & \multirow[t]{5}{*}{0.847} & \multirow[t]{5}{*}{0.553} \\
\hline & FOP2 & 0.573 & & \\
\hline & FOP3 & 0.720 & & \\
\hline & FOP4 & 0.846 & & \\
\hline & FOP5 & 0.860 & & \\
\hline
\end{tabular}

